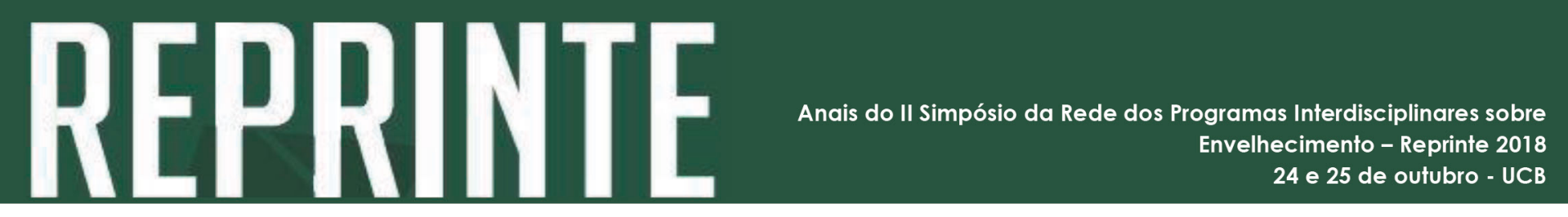

http://dx.doi.org/10.5335/rbceh.v16i1.9917

\title{
21) 0 Idoso e a espiritualidade: aspectos positivos no enfrentamento do envelhecimento
}

\author{
Lúcia Emília dos Santos Veras Muniz, Fernanda Silveira Tavares²
}

\section{Resumo}

O processo de envelhecimento traz, em seu conjunto, situações e emoções que podem tornar-se complicadas e de difícil processamento para a mente do indivíduo, incluindo as questões da finitude da vida, seu sentido e objetivo1. Com isso, a espiritualidade vem como ferramenta útil para a elucidação dos novos questionamentos advindos dessa nova fase fisiológica, a fim de ser meio de suporte emocional e psicológico2. A espiritualidade causa intenso encontro com questionamentos íntimos e como fator intrínseco ao ser humano3. Ademais, a Organização Mundial de Saúde, no ano de 1988, colocou a espiritualidade como participante do conceito de saúde, não se valendo de crenças, ou até mesmo práticas religiosas definidas4. Dessa forma, a avaliação da saúde como um todo deve incluir também a análise da espiritualidade de um indivíduo, sem interferências ou julgamentos pessoais5. Objetivos: Observar os potenciais benefícios da espiritualidade no processo de envelhecimento. Métodos: Revisão narrativa por meio de seleção de artigos disponíveis em meio eletrônico que se adequem à temática sugerida. Resultados: A maioria dos estudos assume que em quase todas as culturas, a espiritualidade e suas manifestações são benéficas no processo global do envelhecimento, trazendo integração social e aspectos positivos na saúde psíquica como um todo, seja no enfrentamento de problemas, seja na aceitação de limitações e da finitude. Dessa forma, fornece alicerces mentais e embasamento para suas questões existenciais e familiares. Conclusão: A espiritualidade deve ser incentivada no idoso, relembrando sempre que este fator não está obrigatoriamente associado à prática religiosa.

Palavras-chave: cuidados paliativos, envelhecimento, espiritualidade

\section{Introdução}

O processo de envelhecimento traz, em seu conjunto, situações e emoções que podem tornar-se complicadas e de difícil processamento para a mente do indivíduo, incluindo as questões da finitude da vida, seu sentido e objetivo (SANTOS, 2007). Com isso, a espiritualidade vem como ferramenta útil para a elucidação dos novos questionamentos advindos dessa

1 Graduanda em Medicina da Universidade Católica de Brasília. Endereço para correspondência: QS 07 Lote 01 EPCT - 71966-700 - Águas Claras - Taguatinga - DF. Email: lucia.e.muniz@hotmail.com

2 Doutoranda no Programa de Pós-Graduação em Gerontologia da Universidade Católica de Brasília e professora no curso de Medicina. Email: fernanda.endocrino@gmail.com 
nova fase fisiológica, a fim de ser meio de suporte emocional e psicológico (MENDONCA et al, 2018).

A espiritualidade causa intenso encontro com questionamentos íntimos e é fator intrínseco ao ser humano (PANZINI et al, 2011). Ademais, a Organização Mundial de Saúde, no ano de 1988, colocou a espiritualidade como participante do conceito de saúde, não se valendo de crenças, ou até mesmo práticas religiosas definidas (GOMES et al, 2014). Dessa forma, a avaliação da saúde como um todo deve incluir também a análise da espiritualidade de um indivíduo, sem interferências ou julgamentos pessoais (ARAÚJO DOS REIS; DE OLIVA MENEZES, 2017).

\section{Objetivos}

Observar os potenciais benefícios da espiritualidade no processo de envelhecimento.

\section{Métodos}

Revisão narrativa por meio de seleção de artigos disponíveis em meio eletrônico que se adequem à temática sugerida.

\section{Resultados}

A maioria dos estudos assume que em quase todas as culturas, a espiritualidade e suas manifestações são benéficas no processo global do envelhecimento, trazendo integração social e aspectos positivos na saúde psíquica como um todo, seja no enfrentamento de problemas, seja na aceitação de limitações e da finitude. Dessa forma, fornece alicerces mentais e embasamento para suas questões existenciais e familiares.

\section{Conclusão}

A espiritualidade deve ser incentivada no idoso, relembrando sempre que este fator não está obrigatoriamente associado à prática religiosa.

\section{Elderly and spirituality: positive aspects in coping with aging.}

Keywords: palliative care, aging, spirituality

\section{Referências}

ARAÚJO DOS REIS, Luana; DE OLIVA MENEZES, Tânia Maria. Religiosidade e espiritualidade nas estratégias de resiliência do idoso longevo no cotidiano. Revista Brasileira de Enfermagem, v. 70, n. 4, 2017. 
MENDONCA, Angelo Braga et al. Aconselhamento e assistência espiritual a pacientes em quimioterapia: uma reflexão à luz da Teoria de Jean Watson. Esc. Anna Nery, Rio de Janeiro, v. 22, n. 4, e20180081, 2018. Available from <http://www.scielo.br/scielo.php?script=sci_arttext\&pid=S1414-81452018000400601\&l$\mathrm{ng}=\mathrm{en} \& \mathrm{nrm}=\mathrm{iso}>$. access on 28 Sept. 2018. Epub July 02, 2018. http://dx.doi.org/10.1590/2177-9465-ean-2018-0081.

PANZINI, Raquel Gehrke et al. Validação brasileira do Instrumento de Qualidade de Vida/espiritualidade, religião e crenças pessoais. Revista de saúde pública, v. 45, p. 153-165, 2011.

SANTOS, F. M. T. D. As emoções nas interações e a aprendizagem significativa. Ensaio Pesquisa em Educação em Ciências. Belo Horizonte, 2007, 9(2), 173-187. 